\title{
IUCN in Retrospect and Prospect
}

\author{
by \\ Lee M. Talbot, M.A., Ph.D.(California at Berkeley) \\ Director-General of IUCN 1980-82, World Conservation Centre, Avenue du Mont-Blanc, \\ 1196 Gland, Switzerland; \\ Senior Scientific Adviser on Conservation and Natural Resources, ICSU; \\ Director of Scientific and International Activities, President's Council on Environmental Quality, \\ Washington, $D C, 1970-78$.
}

\section{INTRODUCTION}

The International Union for Conservation of Nature and Natural Resources (IUCN) is a unique, international but independent, organization which promotes and carries on scientifically-based actions for conservation throughout the world. In part it is a union of sovereign states, governmental agencies, and nongovernmental organizations, joined together in their concern for the need to conserve Man's environment and in their common commitment to effective action for that objective. In part it is a vast network of scientists and others with special expertise in virtually all aspects of environmental conservation, representing nearly every nation of the world; and in part it is an operational body with central headquarters at Gland in Switzerland and separate units in three other countries - dealing, respectively, with environmental law, conservation monitoring, and technical assistance. In the last three years, IUCN has conducted conservation activities in more than 140 countries.

Although founded as long ago as 1948, though admittedly under a rather different name, IUCN remained, until recently, relatively little known. In part because of the complexity of its organization and in part because of its recent years' rapid expansion of structure and activities, IUCN today remains still only partially known even to many of those who are closely associated with it. Consequently, the purpose of this paper is to provide an overview of IUCN today - of what it is and how it works. However, to place this discussion in perspective, it is useful first to give some brief consideration to IUCN's antecedents and history - namely, how and why it came about.

\section{BACKGROUND}

IUCN was founded in 1948, following widespread realization that conservation was an international problem which required an international approach and due cooperation. This fact had been recognized considerably earlier, particularly through much of the past century, and in the early years of the present century a number of tentative efforts were made to establish an international institution for conservation. Thus for example on the initiative of the Swiss zoologist Paul Sarasin, an Advisory Commission for the International Protection of Nature was agreed to in 1913 by delegates of 17 nations meeting in Berne, but the first world war precluded its effective implementation.

Subsequently there were various other initiatives, mostly by individual nations, which met with varied degrees of success because of war and other factors. However, they all contributed to a growing recognition of the need to develop effective institutions to deal with conservation on an international basis, and each in its own way contributed to what later became IUCN. For example in 1928, under the inspiration of P.G. van Tienhoven, of Amsterdam, conservation bodies from the Netherlands, France, and Belgium, together with the International Union of Biological Sciences, founded the International Office for the Protection of Nature, which was later, in effect, merged with IUCN, while in 1930 Harold J. Coolidge, of the United States, founded the American Committee for International Wildlife Protection, which also later played an important role in the founding and early years of IUCN (Baer, 1968; Berwick, 1969; Harroy, 1969; Elliot, 1973; Talbot, 1980; Mence, 1981).

The Second World War brought in its wake wide recognition of the urgent need for international cooperation in many aspects of human activity. Of course the establishment of the United Nations and its specialized agencies was a dramatic manifestation of this recognition. In the field of conservation, a postwar Conference to consider establishing an international organization for conservation was held in Basel, Switzerland, in 1946. This led to a further Conference in Switzerland at Brunnen in the following year, which agreed that an 'International Union for the Protection of Nature' should be created under the auspices of UNESCO, and a provisional Union was set up under the administration of the Swiss League for the Protection of Nature. Subsequently the French Government and UNESCO convened a Conference at Fontainebleau, where, on 5 October 1948, representatives of 18 governments, seven international organizations, and 107 national conservation organizations, signed the Constitutive Act of the Union.

This Act and its 'Statutes', with subsequent relatively minor amendments, still govern IUCN. The original Preamble and Objects are as follows:

\section{Preamble}

Whereas the term 'Protection of Nature' may be defined as the preservation of the entire world biotic community, or Man's natural environment, which includes the Earth's re- 
newable natural resources of which it is composed, and on which rests the foundation of human civilization;

Whereas natural beauty is one of the higher common denominators of spiritual life;

Whereas civilization has achieved its present high development by finding ever-more-effective means for exploiting these resources, and moreover, soils, water, forests, wild life, and wilderness areas, are of vital importance for economic, social, educational, and cultural, reasons;

Whereas the time has come when human standards of living are being depressed because natural resources are becoming inadequate for their maintenance;

Whereas this trend may be reversed if people are awakened in time to a full realization of their dependence upon exhaustible natural resources and recognize the need for their protection and restoration as well as for their wise and informed administration in order that the future peace, progress, and prosperity, of mankind may be assured;

Whereas 'Protection of Nature' is a matter of vital concern to all nations, and the furthering of it is the primary concern of no single effective international agency;

Whereas it would be of assistance to various governments, the United Nations and its Specialized Agencies, and other interested organizations, if an effective international agency were established for the 'Protection of Nature';

Therefore the governments, public services, organizations, institutions, and associations, concerned with these matters represented at Fontainebleau have hereby established a union known as the 'International Union for the Protection of Nature', hereinafter referred to as the Union, and have agreed as follows:

\section{objects}

1) The Union shall encourage and facilitate cooperation between governments and national and international organizations concerned with, and persons interested in, the 'Protection of Nature'.

2) The Union shall promote and recommend national and international action in respect to the preservation, in all parts of the world, of wild life and the natural environment, soils, water, forests including the protection and preservation of areas, objects, and fauna and flora having scientific, historic, or aesthetic, significance by appropriate legislation such as the establishment of national parks, nature reserves, and monuments and wild life refuges, with special regard to the preservation of species threatened with extinction.

3) The Union shall collect, analyse, interpret, and disseminate, information about the 'Protection of Nature'. It shall distribute to governments and national and international organizations, documents, legislative texts, scientific studies, and other information concerning the 'Protection of Nature'.

As used by IUCN's Founders, the term 'Protection of Nature' clearly had a meaning that is somewhat parallel with today's use of the term 'conservation' in the sense of the World Conservation Strategy (1980). The original Preamble, for example, speaks of the 'preservation of the entire world biotic community, or Man's natural environment, which includes the Earth's renewable natural resources of which it is composed and on which rests the foundation of human civilization'; and of the 'need for their (exhaustible natural resources) protection and restoration as well as for their wise and informed administration in order that the future peace, progress, and prosperity, of Mankind may be assured'.

\section{MEMBERSHIP}

IUCN was founded as, and remains, an international body in which delegates of governments, representatives of scientific associations, and others of the nongovernmental community, can meet on an equal footing. Classes of voting membership in IUCN are: States, Government Agencies, and National and International Nongovernmental Organizations. States must be States which are members of the United Nations or of any of its Specialized Agencies, or of the International Atomic Energy Agency or parties to the Statutes of the International Court of Justice. Government Agency members are agencies which are part of the machinery of Governments of such States.

In any matter requiring voting by the Membership, the votes of the governmental members taken as a whole are equal to the votes of the nongovernmental members taken as a whole. Consequently neither category of members can dominate the organization. Recognizing that the global significance of conservation must override partisan political considerations, IUCN was established and remains as a totally non-political organization. Criteria for membership are limited to the organization's interest in conservation of Nature and natural resources, and objections to membership can only be based on grounds of insufficient interest in conservation or possible conflict of interest or violations of objectives indicated in IUCN's Statutes.

IUCN therefore provides a unique bridge between governments and the nongovernmental community concerned with conservation, and it represents virtually the last truly international forum where representatives of all nations may meet in a totally non-political context. IUCN's memberships at the start of 1983 include 58 State Members, 118 Government Agency Members, 292 National Nongovernmental Organizations, 25 International Nongovernmental Organizations, and 6 Affiliates. A total of 114 nations are thus represented.

\section{SOURCES OF SUPPORT}

The primary weakness in IUCN's original - and subsequent-organization has been the absence of an adequate basis for financing the Union and its necessarily ambitious objectives. Membership dues were initially set at extremely low figures and, particularly in the governmental categories, they remain far too low for a world body. For most of IUCN's first two decades, the staff was limited to a handful of volunteers and underpaid individuals, usually with a part-time Secretary-General. The funds were so limited that there were a number of times when the ability of IUCN to carry on was in doubt. But through the generosity and devotion of a small number of individuals and organizations, financial crises were overcome and IUCN did continue to grow.

In 1961 , chiefly concerned about the chronically precarious financial position of IUCN itself and about the associated lack of funds to carry out the international conservational actions which it, in large part, identified, IUCN Vice-President Peter Scott and others associated 
with the Union proposed to solve the problem through establishing a world fund-raising organization. The plan was approved in principle in April 1961 at a meeting of the IUCN Executive Board in Morges, Switzerland, and later that year the World Wildlife Fund (WWF) was legally established, with offices in IUCN's then headquarters in an old hotel-building in Morges (cf. Berwick, 1969; Vollmar, 1971).

At present, WWF International has its headquarters again jointly with IUCN in what is now called the 'World Conservation Centre', in Gland, Switzerland, and has 25 National Organizations (formerly called 'Appeals') which raise funds and pursue conservation objectives in their own countries. Over the years, WWF has made an important contribution to IUCN's base budget, and has also provided funding for hundreds of field conservation projects throughout the world.

In 1969, thanks in large part to a Ford Foundation grant secured through the efforts of IUCN's then President Harold J. Coolidge and others, it was possible for the Union to obtain a significantly larger, more functional and professional, secretariat.

Since that time the professional strength and operational capability of IUCN have been gradually increased, as has the strength of the Union's volunteer network of expertise - largely through its Commissions (see below), which have long constituted a major facet of its strength and viability.

The establishment of the United Nations Environment Programme (UNEP) late in 1972 brought IUCN into a new relationship with the UN system. Since its founding, in part by UNESCO under Sir Julian Huxley, IUCN had always had selected links with various parts of the UN system. UNEP, however, had responsibilities specifically focused on the environment, and this created a natural partnership with IUCN's unique structure and access to pertinent world-wide scientific expertise. Since then, IUCN has had increasingly effective cooperation not only with UNEP but also with several other parts of the UN system.

At present (in the 1983 budget) the major sources of IUCN's basic support in very approximate percentages are: (1) governmental contracts and grants (including support for the CITES secretariat), $30 \%$; (2) WWF $21 \%$ plus another 7\% to cover costs of IUCN management of WWF-financed projects; (3) Membership dues, 20\%; (4) UNEP contracts $13 \%$, and miscellaneous grants, contracts, and publications, $9 \%$.

\section{THE FOCUS OF THE ORGANIZATION}

As noted above, IUCN started life as the International Union for Protection of Nature (IUPN). To the founders, 'Protection of Nature' included the preservation of species and areas, as well as of natural beauty and ethical values - and the restoration, wise use, and administration, of natural resources as a basis for development to assure 'the future peace, progress, and prosperity, of Mankind'. A review of the themes covered by the international technical meetings convened mostly bienni- ally or triennially by IUCN since its founding, shows that there has been a consistent balance between what has come to be considered the 'preservation-oriented' and the 'development-oriented' aspects of conservation.

1. Lake Success [NY, USA] 1949: Education and Nature protection. The role of ecological research in the conservation of natural resources.

2. The Hague [Netherlands] 1951: Rural landscape as a habitat for fauna and flora in densely populated countries. Management of Nature reserves.

3. Caracas [Venezuela] 1952: Consequences of the use of fire for agriculture. Protection of endemic species on small islands.

4. Salzburg [Austria] 1953: Protection of Nature and tourism. Protection of fauna and flora at high altitudes.

5. Copenhagen [Denmark] 1954: Arctic fauna. Insecticides, herbicides, and their noxious effects on mammals and birds.

6. Edinburgh [Scotland, UK] 1956: Management problems of Nature reserves. Rehabilitation of areas devastated by human disturbance. Relationship of ecology to landscape planning.

7. Athens [Greece] 1958: Erosion and civilizations. Conservation education. Biological hazards resulting from atomic wastes.

8. Warsaw [Poland] 1960: The ecological effects of biological and chemical control of undesirable plants and animals. Ecology and management of wild grazing animals in temperate zones.

9. Nairobi [Kenya] 1963: The ecology of Man in the tropical environment.

10. Lucerne [Switzerland] 1966: Towards a new relationship of Man and Nature in temperate lands. Ecological impact of recreation and tourism upon temperate environment.

11. New Delhi [India] 1969: Conservation in land-use planning; soil and water resources, especially in mountain regions; wildlife resources and forestry. Effects of pollution in natural ecosystems. Some aspects of wildlife utilization and management. International Biological Programme: the CT survey of undisturbed oceanic islands; current research in India and its relevance to conservation. Problems of threatened species. The National Park situation in southern Asia, with special reference to the role, management, and economic and social functions, of national parks in densely populated nonindustrial regions. Environmental conservation education among the population of rural and woodland areas. Creative conservation in an agrarian economy.

12. Banff [Alberta, Canada] 1972: Conservation for development - environmental quality in a changing world. National and international environmental policies. Ecological multidisciplinary approach to development planning. Resource utilization and conservation. Management of nonagricultural rural lands. Dynamics of vanishing species and their habitats. Conservation of marine habitats.

13. Kinshasa [Zaire] 1975: Conservation for decisionmakers. Conservation problems in tropical Africa. Zoos and botanic gardens in conservation programmes. International conventions. Public awareness of conservation values. Support for conservation action in countries with major conservation problems but limited financial resources.

14. Ashkhabad [Turkmenistan, USSR] 1978: State of world conservation. Charter for Nature. IUCN's Conservation Programme. World Conservation Strategy. Categories, objectives, and criteria, of protected areas.

15. Christchurch [New Zealand] 1981: Conservation and Society: The World Conservation Strategy in Action. 
By 1956 it had become apparent to the Union's leadership and members that the name 'International Union for Protection of Nature' had come to project a much more limited and perhaps more defensive or sentimental image than was warranted by the vitally important work to which it was devoted. Consequently, at the General Assembly in Edinburgh in 1956, the designation IUPN was changed to the present, namely the International Union for Conservation of Nature and Natural Resources (IUCN).*

The General Assembly of 1969 represented a turning point for IUCN, not only in terms of its potential for increased professional operating capabilities but also most significantly in terms of its strategic orientation. For it started to shift from a largely 'fire-brigade' reactive approach to individual problems, into the direction of anticipating future trends and hence towards a new strategic approach to world-wide conservation problems and alleviation of their basic causes.

The Assembly affirmed that IUCN was concerned with the 'quality of life'-with the physical, educational, social, and aesthetic, values which add richness, meaning, and satisfaction, to human experience. At the same time it was concerned with assuring the continued possibility of life. The Assembly agreed that, to this end, IUCN should initiate and promote scientifically-based action which will ensure perpetuation and enhancement of the living world-Man's natural environment-and the natural resources on which all living things depend. 'Conservation' was defined as management (which includes survey, research, administration, preservation, and utilization, and also implies education and training) of air, waters, soil, minerals, and living species including Man, so as to achieve the highest sustainable quality of life.

The strategic approach and emphasis on sustainability of quality of life initiated at New Delhi, finally found global expression in 1980 in the World Conservation Strategy, which was prepared over a period of years by IUCN with the advice, cooperation, and financial assistance, of UNEP and the World Wildlife Fund (WWF), and in collaboration with FAO and UNESCO (Talbot, 1980). The implementation of the strategic approach (in addition to the traditional reactive one) has only become a major part of IUCN's field operations in the past few years.

\section{FUNCTIONS OF THE UNION}

To promote and achieve conservation, IUCN's major activities may be categorized in four main functions: (1) monitoring, (2) evaluating and planning, (3) promoting, and (4) implementing. These will now be considered in more detail.

* Although the even more prolix French rendering conforms to the customary insertion of extra articles in that language, it does not excuse the common though erroneous insertion of 'the' before 'Conservation' by many when attempting to use the English name for the Union.-Ed.
(1) Monitoring conservation conditions world-wide:The status of species and areas is monitored in a systematic way by the computerized IUCN Conservation Monitoring Centre in southern England, as is the status of conservation legislation by IUCN's Environmental Law Centre in Bonn, West Germany. Other types of conservation information are provided by IUCN's vast network, which includes its membership, its commissions, and the hundreds of specialists involved in field projects and other operations of the Union-including the Conservation for Development Centre and the international convention secretariats.

(2) Evaluating and planning:-IUCN assesses and evaluates the information received through monitoring, and develops plans for actions to deal with the present and anticipated conservation problems. The plans are at three levels: strategic, programme, and projects. The World Conservation strategy is an example of the strategic level. For the programme level, IUCN each year updates and rolls forward a three-years' 'Conservation Programme for Sustainable Development', which is essentially a global plan of priority action for conservation, part of which comprises IUCN's direct activities within its approved budget, and the rest of which represents actions for which IUCN seeks additional support in funding or in cooperation with WWF, UN bodies, Members, Governments, and/or organizations. The programme is developed through a structured annual process involving consultation with the membership, commissions, and other components of the network. This process, initiated by previous Director General David Munro and his Programme Director Adrian Phillips, is fundamental to IUCN's operations. At the project level IUCN staff, consultants, or members, develop plans for specific projects to implement the various parts of the programme under consideration.

(3) Promoting conservation action:- The resources available to IUCN and to conservation in general are infinitessimally small relative to the magnitude of the environmental challenges which we face. Furthermore, most of the actions which affect the environment, beneficially or otherwise, are taken by governments - either directly or through intergovernmental organizations. Consequently IUCN seeks to promote implementation of its developed plans by governments, intergovernmental agencies, and nongovernmental bodies. To this end the World Conservation Strategy and annually updated IUCN Programme are augmented by a variety of direct contacts on specific issues.

(4) Implementation:- Where it is necessary and where resources are available, IUCN provides assistance, advice, and sometimes direct implementation of a particular conservation action on the basis identified through its planning process. In part this is achieved through the 300 or so projects that are financed annually by WWF. The project proposals are in most cases developed through the IUCN network, screened by IUCN, and, if approved, managed by the IUCN Project Management Department.

Recently, IUCN has very greatly augmented its field operational capabilities to undertake conservation action on the ground, and also to provide technical conserva- 
tion assistance towards implementing the World Conservation Strategy. This has been accomplished in part through substantially expanded conservation operations within IUCN's programme but carried out under contract with individual governments or UN agencies, and in part through the establishment in 1981 of the Conservation for Development Centre. The Centre seeks to assure that the priorities of conservation are recognized in the plannning and implementation of economic development, and provides a unique source of technical assistance in conservation for developing countries and development assistance agencies.

In less than two years the Centre has become well established, internationally recognized, and has developed active and rapidly-expanding activities throughout the world. In connection with the Centre, IUCN and the International Institute for Environment and Development have established the Joint Environmental Services (JES) as a cooperative endeavour. JES is already operational and has an office in Washington, DC.

In these ways IUCN has increased its field operational capabilities -- with financing which is additional to its regular budget and additional to the WWF projects, and which has increased from a mere 13,000 S.Frs in 1980 to several million S.Frs in 1983.

\section{GOVERNANCE OF THE UNION}

Delegates of the IUCN Members meet every three years at the General Assembly, which is the highest policy-organ of the Union. The General Assembly reviews progress in the previous triennium, considers and approves the draft programme and budget for the coming triennium, determines the general policy of IUCN, and elects the Council.

The IUCN Council consists of the elected President, three elected Regional Councillors from each of 8 geographic regions of the world, the chairmen of IUCN Commissions, and up to 5 co-opeted Councillors (i.e. councillors appointed by the elected members of Council). The Council serves as the governing body of IUCN, meeting at least once a year and representing the General Assembly between its meetings. There is also a smaller executive body, the Bureau, which meets at least twice a year, consisting of the President, Vice-Presidents, Treasurer, and others appointed by Council.

The Council appoints the Director-General, who is the chief executive officer of IUCN, and, as such, is responsible for implementing the policy and for the finances and accounting of IUCN.

\section{STRUCTURE OF THE UNION}

The physical structure of IUCN includes the headquarters (located jointly with WWF in Gland, near Geneva, Switzerland), four units of the Conservation Monitoring Centre ( 2 located at Cambridge and 2 at Kew, England, UK), the Environmental Law Centre at Bonn, West Germany, and (jointly with IIED) the Joint Environmental Services office in Washington, DC, USA.
At the headquarters in Gland are several units in addition to the directorate:

- Membership and Executive Affairs handle all matters concerned with the membership as well as publications and public affairs. IUCN produces a two-monthly Bulletin and quarterly Parks journal, a monthly conservation news service for members' publications and other environmental periodicals world-wide, and a variety of publications that are issued directly from IUCN or jointly with various cooperating organizations. As of 1983, the scientific Journal Ambio is being published by the Swedish Royal Academy of Sciences in association with IUCN. One significant result of IUCN's work is the volume of publications that flows from assemblies, conferences, technical meetings, and projects. These are mainly scientific in nature and form an important contribution to the world's conservation literature. A complete list of IUCN publications can be obtained by writing to Publication Services, IUCN, World Conservation Centre, Avenue du Mont-Blanc, 1196 Gland, Switzerland.

- Commission Services and Centres has responsibility for the IUCN Commissions, the Environmental Law Centre (ELC) at Bonn, and the Conservation Monitoring Centre (CMC) in England (see above and below). The ELC maintains a computerized international environmental legislation data-base, produces a number of specialized publications in its field, and provides assistance with environmental legislation at national and international levels. The CMC was formally established in 1980 from formerly separate activities initiated by the Commissions, and is now a centrally-managed facility with four computerized units monitoring the world-wide status of endangered animals, plants, wildlife trade, and protected areas. In addition to producing the standard world reference materials (e.g. the Red Data Books), the CMC provides conservation data services to a wide variety of governments, UN bodies, and other organizations.

- Regional and Project Services has responsibility for screening, managing, and evaluating, field projects world-wide, and for maintaining liaison with the various regions.

- CITES Secretariat is administered by IUCN on behalf of UNEP and the States that are parties to this Convention on International Trade in Endangered Species of Wild Fauna and Flora.

IUCN also handles, on behalf of UNESCO, technical responsibilities for the natural areas involved in the Convention concerning the Protection of the World Cultural and Natural Heritage. In both of these Conventions, as in many others, IUCN initiated development of the Convention and produced the initial drafts. IUCN also has responsibility for the bureau functions on behalf of the Ramsar Convention on Wetlands of International Importance Especially as Waterfowl Habitat.

- The Conservation for Development Centre, also at Gland, has been described above.

- Finance and Management Services are administered jointly with WWF, as both organizations share the same building and many of the facilities which it contains. 
COMMISSIONS

One of IUCN's greatest strengths lies in its access to much of the world's conservation expertise, to which access the IUCN Commission structure is a keystone. The Commissions are voluntary bodies, currently comprising nearly 1,500 scientists and other specialists on environmental affairs. The functions of the Commissions, as specified in the Statutes and Regulations, are threefold:

1) 'to bring to the attention of the General Assembly and the Council any matter within their specialized fields of competence [which] they deem advisable relating to the policy and programme of work of IUCN;'

2) 'to provide advice within their specialized fields of competence on any matter referred to them by the General Assembly, the Council, the Bureau, or the Director-General;' and

3) 'to undertake tasks within the approved programme of work of IUCN assigned to them by the Council, the Bureau, or the Director-General, respecting always the agreed policy of IUCN, any guidelines laid down by the Council or the Bureau, and [with] the accountability of the DirectorGeneral.'

Exemplifying the kind of 'tasks' which effective Commissions can perform is the World Parks Congress, which was held on Bali, Indonesia, in October 1982.* Five years earlier, the Commission on National Parks and Protected Areas** was requested by the Council to plan and organize the Congress on behalf of IUCN. On an entirely voluntary basis, the Commission initiated negotiations with the host government, developed the plans and programme, arranged for financial and other support, and saw to it that the Congress, attended by over 500 specialists and others from some 60 nations, was an outstanding success.

Each Commission has a Chairman, who is elected by the General Assembly and serves on Council. Members of Commissions are proposed by the respective Chairmen and approved by Council. Commission Executive Officers, located at Gland, provide liaison and facilitate each Commission's work.

The six IUCN Commissions currently are of (1) Ecology, (2) Education, (3) Environmental Planning, (4) Environmental Policy, Law, and Administration, (5) National Parks and Protected Areas, and (6) Species Survival. The Commissions are integral parts of the IUCN structure and work. In some respects they are analogous to the standing Committees or Commissions of a National Academy of Sciences.

* See the 'Important Prospect' by the former Executive Officer of the Commission, Harold K. Eidsvik, of Canada, published on page 170 of our last Summer issue, and the report by Raisa Scriabine, IUCN Director of Public Affairs, published on pp. 78-9 of the present issue.-Ed.

** Described by its Executive Officer, Jeffrey A. McNeely, and its Chairman, Dr Kenton R. Miller, on pages 13-21 of this issue, as an invited outstanding example of the functioning of an IUCN Commission.-Ed.
CONCLUSION

Even in an article of this length it has been possible to provide only an outline of IUCN and its manifold activities, attempting as they do to meet the extraordinarily numerous and often complex conservation problems of our time. IUCN's beginnings were relatively humble, but the vision of its founders was such that, over the years, the Union has developed to meet more and more of the evolving challenges to world conservation. It is continuing to develop and also expand rapidly: Thus in the past two-and-a-half-years alone there has been an increase of $16 \%$ in the nongovernmental membership, and an increase of $12 \%$ in the full state membership. IUCN's operational capabilities have greatly expanded, with consequent increasing activities, recognition, and effectiveness world-wide. The fact that this is occurring even in these financially difficult times is further evidence of the importance of the organization's role and the wisdom of its founders.

But while we can look with considerable pride at the past accomplishments and development of the Union, one must also look with awe at the challenges to conservation now and in the years ahead. There was indeed a need for an IUCN at its founding in 1948; there is a significantly increased need today; and there will be a vastly greater need in the future.

\section{SUMMARY}

IUCN is a unique, international but independent, organization which promotes and carries on scientificallybased action for conservation throughout the world. Founded originally for the 'Protection of Nature', it has evolved greatly in the intervening nearly 35 years in response to current needs, and now occupies a very prominent position in the environmental/conservational movement to withstand ever-increasing human population-pressures through rational use of resources and seeking to assure that development is environmentally sound.

After accounts of the Background, Membership, Sources of Support, and Focus, of IUCN, its functions and modus operandi are outlined, followed by details of its Governance and Structure (including the Conservation for Development Centre). It is contended that 'One of IUCN's greatest strengths lies in its access to much of the world's conservation expertise' particularly through its Commissions, which currently comprise those of (1) Ecology, (2) Education, (3) Environmental Planning, (4) Environmental Policy, Law, and Administration, (5) National Parks and Protected Areas, and (6) Species Survival.

The terminal contention of this general account of its establishment and work is that, while IUCN 'can look with considerable pride at the past accomplishments and development of the Union', we must all regard with awe 'the challenges to conservation now and in the years ahead. There was indeed a need for an IUCN at its founding ... and there will be a vastly greater need in the future.' 


\section{REFERENCES}

BaER, JEAN G. (1968). Aperçu historique de la protection de la Nature. Biological Conservation, 1(1), pp. 7-11.

Berwick, E.J.H. (1969). The International Union for Conservation of Nature and Natural Resources: Current activities and situations. Biological Conservation, 1(3), pp. 191-9.

ElLiot, SIR Hugh (1973). The first quarter-century of IUCN: Looking back and looking ahead. Pp. 15-55 in 1973 IUCN Yearbook. IUCN, Morges, Switzerland: $130 \mathrm{pp}$.

HaRroy, Jean-PaUl (1969). L'Union Internationale pour la Conservation de la Nature et de ses Ressources: Origine et Constitution. Biological Conservation, 1(2), pp. 106-10.
Mence, Anthony J.['Tony'] (Ed.) (1981). IUCN: How it Began How it is Growing Up. IUCN, Gland, Switzerland: $43 \mathrm{pp}$. (mimeogr.).

TALBOT, LEE M. (1980). The world's conservation strategy. Environmental Conservation, 7(4), pp. 259-68.

Vollmar, Fritz (1971). The World Wildlife Fund in the 1970s. Biological Conservation, 3(2), pp. 85-7.

World Conservation Strategy (1980). World Conservation Strategy: Living Resource Conservation for Sustainable Development. IUCN-UNEP-WWF (obtainable from IUCN, Avenue du Mont-Blanc, 1196 Gland, Switzerland: vii + ca 43 pp. + maps. 